\title{
The Effect of Service Quality and Value of Five-Star Hotel Services on Behavioral Intentions with the Role of Consumer Satisfaction as Mediator
}

\author{
Vasco Adato H. GOELTOM ${ }^{1}$, Yustisia KRISTIANA ${ }^{2}$, J. JULIANA ${ }^{3}$, Innocentius BERNATO ${ }^{4}$, Rudy PRAMONO ${ }^{5}$
}

Received: August 01, 2020 Revised: October 05, 2020 Accepted: October 15, 2020

\begin{abstract}
This study aims to improve knowledge of consumers' decision-making by testing a conceptual model that considers the hotel's service quality and service value toward customers' behavioral intentions using a mediator, which is the role of consumers' satisfaction. The object of this research is five-star hotels, which has become a significant segment of the general hotel industry and is undergoing rapid expansion. This research is a quantitative research using questionnaire as the sampling method answered by people who have stayed at five-star hotels before. The total of 150 valid respondents were used in this study. The collected data was processed by a statistical tool software, Partial Least Square (PLS). The major findings of this research showed that the relations between service quality and service value of five-star hotels do not have significant positive impact on consumers' behavioral intention, nonetheless the mediation analysis shows that customers' satisfaction partially mediates service quality and service value with consumers' behavioral intentions to stay. It means that in this case, consumers' satisfaction has an important role to mediate service value quality and service value. As a result, the study shows that four out of six hypotheses are supported. A couple of recommendations are suggested for further research.
\end{abstract}

Keywords: Hotel Service, Service Quality, Service Value, Customer Satisfaction, Behavioral Intention

JEL Classification Code: L00, L83, Z31

\section{Introduction}

Quality of service, consumer satisfaction, and loyalty in the hotel business are main principles for building a long-term relationship between customer and organization. However, service quality conditions affect the company's competitive advantage by maintaining customer protection, and with this, emerging market contribution (Park et al., 2004; Morash \&

\footnotetext{
${ }^{1}$ First Author. Pelita Harapan University, Indonesia.

Email: vasco.goeltom@uph.edu

${ }^{2}$ Pelita Harapan University Indonesia.

Email: yustisia.kristiana@uph.edu

${ }_{3}^{3}$ Pelita Harapan University, Indonesia. Email: juliana.stpph@uph.edu

${ }^{4}$ Pelita Harapan University, Indonesia.

Email: innocentius.bernato@uph.edu

${ }^{5}$ Corresponding Author. Lecturer, Pelita Harapan University, Indonesia [Postal Address: MH Thamrin Boulevard 1100, Klp. Dua,

Kec. Klp. Dua, Tangerang, Banten 15811, Indonesia]

Email: rudy.pramono@uph.edu

(c) Copyright: The Author(s)

This is an Open Access article distributed under the terms of the Creative Commons Attribution Non-Commercial License (https://creativecommons.org/licenses/by-nc/4.0/) which permits unrestricted non-commercial use, distribution, and reproduction in any medium, provided the original work is properly cited.
}

Ozment, 1994; Mulyono et al., 2020). Providing excellent services to consumers is very important for the viability of hotels, so it is necessary to understand what consumers expect from their services. Therefore, behavioral intention is key for hotel management to ascertain whether customer would deal with the firm itself (Tran, 2020).

The hotel is a company that provides accommodations that give guests 'home' when away from their homes. Now, five-star hotels are very important in any economy because most international tourists and well-known domestic tourists stay at this hotel. The attractiveness of Indonesian tourism encourages many foreign and domestic players to set up their operational facilities in the country. Therefore, all hotels need to make sure customer satisfaction through providing high quality services to their guests meet their financial and strategic goals. Providing high quality services to guests is very important for the survival of the hotel. Improving employee performance is one of the most important and productive ways for hotels to stay competitive.

On the other hand, given that providing quality service and satisfying consumers has become the purpose of the service provide, service quality and customer satisfaction need to be investigated to find out where the hotel is located 
and to develop right methods that lead to prominence. The impression that tourists will have of the organization as a whole will depend on their interactions with frontline employees, which means that the latter has a role in service quality. However, quality control of services is very important for customer retention. Customer loyalty is the main determinant for an organization's long-term financial performance (Jones \& Sasser, 1995).

The tourism industry continues to develop rapidly in the world, including Indonesia. Quality of service plays an important role in the hospitality industry because there is a need to offer good services. Efficiency cannot be achieved without good and proper service quality standards. Quality assurance of service is very important in a variety of hotels, especially five-star hotels, because, besides exceptional aesthetics, the most important thing is the service that must be basically perfect (McLean, 2019). Service is a solid and conclusive determinant of hotel guest's loyalty that is mediated through the satisfaction of guests. Nevertheless, service quality itself is not enough to ensure customers will be loyal. To earn their loyalty, guests must also be satisfied with the services provided (Maroco \& Maroco, 2013). So, it is important to cut all loss of service quality in this sector to make sure consumers' satisfaction is attained. The construct of contentment has entered the marketing area (Lee \& Seong, 2020). Prior research indicates that consumers' absolute behavioral intentions emanate from their satisfaction, while at the same time satisfaction is the outcome of proficient and decent service quality (Tran \& Le, 2020).

Media Indonesia (2019) mentions that room occupancy rates in five-star hotels in Indonesia from May 2018 to May 2019 are decreased by 3,50\%. Based on the background of the research mentioned above, this study seeks to investigate the decision-making factors that affect the quality of hotel services; the main goals of this study are, thus: 1) to improve understanding of the consumer decision-making process by testing a conceptual model that considers the quality of five-star hotel services, service value, and satisfaction with behavioral intentions; 2) to examine the relationships between five-star hotel service quality factors, satisfaction and service values, and behavioral intentions within the framework of modeling structural equations; and 3) to assess consumer perceptions of the level of service provided by five-star hotels.

\section{Literature Review}

\subsection{Luxury Hotel}

The luxury hotel industry has become a prominent and valuable part of the general hotel industry and is passing through rapid evolution. Danziger (2005) categorizes luxury into four dimensions that put the ideal of luxury into perspective, namely, "luxury as a brand", "luxury as a product feature", "luxury as a need", and "luxury as a power to pursue the passions." Luxury hotels, as the real existence of certain established luxury brands, fall into "luxury as a brand category", namely, about people who consume luxury products and services because they considered as a symbol of luxury and the best quality (Danziger, 2005). "Luxury as a product feature" looks at the specific attributes of the product or service, which in our case means things like the inside and outside decoration of hotel buildings, or the quality and perfection of hotel amenities. The third dimension, "luxury as needs", defines luxury as something above basic needs. For the hospitality industry, accommodation and catering are the primary necessities, while luxury hotels - in this case, five-star hotels - offer services that are above and beyond what is thought of luxurious (Becker, 2009). The last category, "luxury as the power to pursue desire" refers to purchasing posh things to make life feel more pleasing and adequate, for example, spa treatments in hotels.

The luxury hotel segments are divided as follows: 1) luxury major; 2) exclusive luxury; and 3) upper upscale (The World Luxury Index, 2013), which includes five-star hotels. A five-star hotel is arguably the most luxurious one. A five-star hotel is a property that offers guests a top-line luxury level through personal services, a variety of facilities, and advanced accommodation for guests among the most complex to run, which must meet all service, facilities and comfort criteria.

This type of hotel is the most vivacious among other types of hotels in the industry, enjoying special status in prosperous times, but often suffers much when an economic crisis come (Chu, 2014).

\subsection{Service Quality in Hotel Services}

There are some perceptive designs or models that have evolved to check consumers' satisfaction. From a marketing perspective, customer satisfaction is achieved when customer needs and desires are met (Lam \& Zhang, 1999). Understanding exactly what consumers expect is the most important step in defining and delivering high-quality services (Zeithaml et al., 1996). Service quality and customer satisfaction have increasingly been identified as key factors in the battle for competitive differentiation to gain customer retention and customer loyalty (Hersh, 2010; Ka-dampully \& Suhartanto, 2000; Su, 2004). While this is important in all areas of the tourism and lodging industry, the benefits of customer expectations for mid-top hotel services are important to keep customers satisfied and wanting to return (Mohsin \& Lockyer, 2010; Oh, 1999).

Given the growth of services over the past decade, service quality model measures the difference between customer expectations about the general quality of a 
particular service provider group and their perceptions about the actual performance of service providers from that group. The model uses a set of service quality determinants to fill the gap between ideal and perceived products or services, separately from the five fundamental dimensions, namely: physical evidence (tangibility); responsiveness; reliability; assurance; and empathy.

\subsection{Service Value}

The issue of value creation or added value has been widely discussed in consumer and industry marketing literature and is often treated as a major part of the organization's mission and goals statement. Service value is defined as an important variable of customer satisfaction and behavioral intention (McDougall \& Kevesque, 2000). Zeithaml (1988) describes the value perceived conceptually as consumers> overall assessment of the utility of a product based on perceptions about what has been received and what is given. He identified four unique definitions of the construct of values with exploratory investigations: 1) value is a low price; 2) value is whatever I want in a product; (3) value is the equivalence I get for the price I pay; and 4) value is what I get for what I give. Overall, value is an exchange or trade-off between giving (benefit) and giving up (sacrifice). The value of what is given and what is received varies between consumers.

\subsection{Satisfaction}

Company performance leads to customer satisfaction with products or services (Huang \& Feng, 2009). Customer satisfaction is fundamental in the practice of consumer autonomy or sovereignty. In recent research, consumer satisfaction or dissatisfaction has become an important issue for marketing practitioners because of the fast-developing business environment. Consumer satisfaction is defined as an assessment made based on certain service encounters. Satisfaction and loyalty are not substitutes for each other (Bloemer \& Kasper, 1995; Oliver, 1999). It is possible for consumers to stay loyal without feeling very satisfied and being very satisfied, but not yet loyal. Companies must need to get a better understanding of the relationship between satisfaction and behavioral intentions in the corporate environment and to allocate marketing efforts between satisfaction initiatives and behavioral intention programs.

\subsection{Behavioral Intention}

Warshaw and Davis (1985) define behavioral intentions as the extent to which a person has formulated a conscious plan to do or not do some determined future behavior. Consumer behavior primarily links consumer decision-making processes with their consumption choices and experiences.
It also means that consumer behavior includes the feelings and thoughts experienced, and behavior during their buying process. At the same time, it also includes environments that affect emotions, cognition and consumer behavior, such as other consumer comments, advertisement marketing, product price information, packages, product appearance, etc. Compared to variables of service quality or customer satisfaction, the behavior in question is more closely related to real behavior and reflects a higher diagnostic value.

\subsection{Hypotheses}

Current visitors' behavior depends on the extent of gratification with their goals. There is a certain link between visitor satisfaction and their behavioral intentions (Beerli \& Martin, 2004). In addition, if a customer is very satisfied staying in one of the hotels, he will likely visit it again and will gladly recommend it to his friends and/or family (Oliver, 1980). Fornell et al. (1996) and Gooding (1995) say that the causal relationship between values and behavioral intentions of consumers is expected to apply in customer process situations before and after staying in a hotel. Evaluation of service quality that is cognitive oriented and service value leads to evaluations of emotional satisfaction (Cronin et al., 2000). Parasuraman et al. (1988) and Zeithaml et al. (1996) have reported that there is also a certain bound among perceived service quality and behavioral intention.

Anderson et al. (1994) state that consumers' satisfaction entails several events or impressions with services provided and impacted by perceived service quality itself. Satisfaction is a perception or impression and hope (Kotler, 2000). An increase in a level of satisfaction will also increase the potential to repurchase the product or service offered (Buttle, 2004). Therefore, satisfied consumers have a tendency to become loyal consumers, and repeat purchases are more likely to occur. In addition, satisfied consumers are more likely to be tolerant of potential service failures. Furthermore, perceived values are conceptualized as consumer evaluations of perceived benefits and perceived sacrifices (Zeithaml, 1988). Perceived service value will be directly influenced by perceived service quality (Choi et al, 2004). Strengthened by earlier studies of quality which states service quality has an absolute leverage on the value of services (Fornell et al., 1996; Wakefield \& Barnes, 1996). This study formulates the following hypotheses:

H1: Consumer satisfaction is positively related to behavioral intention

H2: The value of service has a positive impact on hotel guests' behavioral intention

H3: There is a positive and direct relationship between the value of service and satisfaction 
H4: Service quality is positively related to behavioral intention

H5: Service quality is positively related to customer satisfaction

H6: Service quality is positively related to service value.

\section{Research Methods and Materials}

\subsection{Research Method}

This research is a quantitative study with cross-sectional time dimension. This study uses a non-probability sampling technique, which does not provide equal opportunities to members of the population selected as sample members. Through quantitative data collection techniques, the instrument used to collect samples is a questionnaire method distributed to respondents who have stayed at five-star hotels before. The structured questionnaire includes a five-point Likert scale.

According to Ferdinand (2006), the sample relies on the amount of index used in all potential variables. The number of samples is the number of indicators multiplied by $5-10$. The determined sample is five times all indicator variables $(30 \times 5=150)$. So the number of respondents needed in this study were 150 people. Some 42 respondents were male (28\%) and 108 female (72\%). Some 108 (72\%) respondents were in the 19-22 age bracket, followed by 20 people $(13.3 \%)$ aged 23 to $29 ; 12$ people $(8 \%)$ aged 30 to $40 ; 10$ people $(6.7 \%)$ aged 40 and older; and no respondent were below 18 years old. A total of $131(87.3 \%)$ respondents were unmarried and 19 (12.7) were married. Furthermore, respondents were dominated by 91 students, accounting for $60.7 \%$ of respondents; $35(23.3 \%)$ were employees; $15(10 \%)$ were self-employed, and nine $(6 \%)$ respondents were in the "Others" category. Respondents who took the questionnaire were guests who had stayed in a five-star hotel before. Some 110 respondents $(73.3 \%)$ answered their last travel destination was for vacation or travel, 25 respondents (16.7\%) for business, and 15 people (10\%) to visit.

The data were processed using the statistical analysis software Smart PLS (Partial Least Square) v.3.3.2.

\subsection{Tables and Figures}

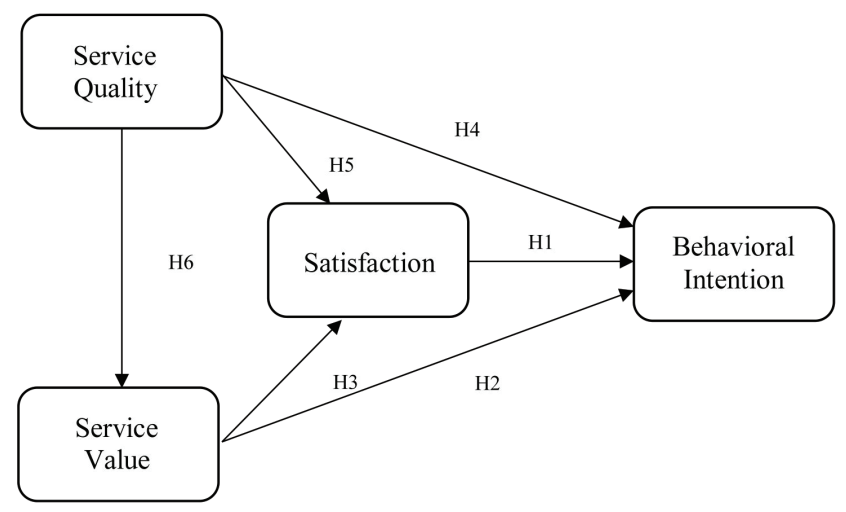

Figure 1: Research Model

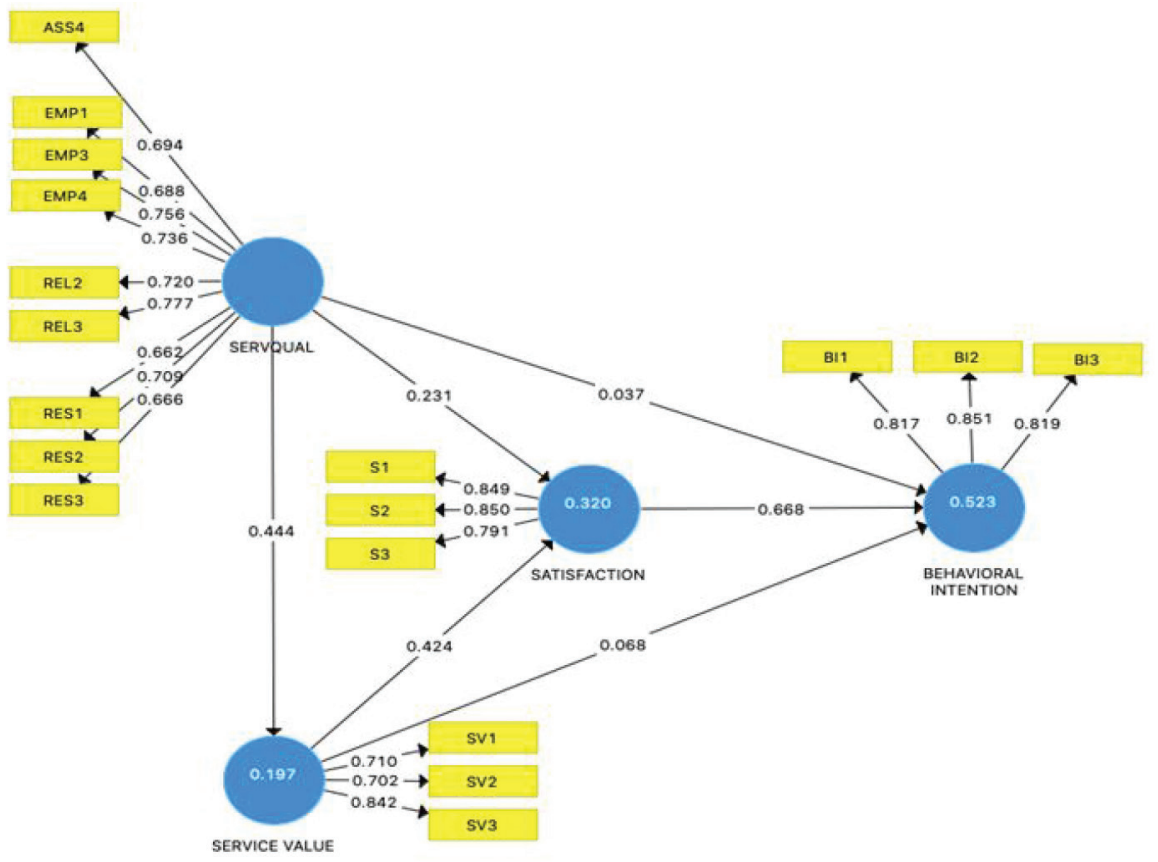

Figure 2: Hypothesis Test Results Model 
Table 1: Evaluation of Expenditure Models

\begin{tabular}{|c|c|c|c|}
\hline Dimension/Variable & Loading Factor & AVE & CR \\
\hline \multicolumn{4}{|l|}{ QUALITY OF SERVICE } \\
\hline Hotel employees have the ability to answer your questions & 0.694 & 0.508 & 0.903 \\
\hline The hotel gives you individual attention & 0.688 & & \\
\hline The hotel has employees who give personal attention & 0.756 & & \\
\hline Hotel employees meet your special needs & 0.736 & & \\
\hline When a hotel promises to do something at a certain time, it happens & 0.720 & & \\
\hline When you have a problem, the hotel shows sincere attention to solve it & 0.777 & & \\
\hline Hotel employees provide fast service & 0.662 & & \\
\hline Hotel employees handle requests or complaints well & 0.709 & & \\
\hline Hotel employees are always willing to help you & 0.666 & & \\
\hline \multicolumn{4}{|l|}{ SERVICE VALUE } \\
\hline I always have a good impression of five-star hotels & 0.710 & 0.569 & 0.797 \\
\hline Hotel rates are reasonable & 0.702 & & \\
\hline I believe that the hotel offers services that match the money spent & 0.842 & & \\
\hline \multicolumn{4}{|l|}{ SATISFACTION } \\
\hline I believe I did the right thing when I decided to stay at a five-star hotel & 0.849 & 0.690 & 0.870 \\
\hline My decision to stay at a five-star hotel was a wise decision & 0.850 & & \\
\hline I am satisfied with the service of a five-star hotel & 0.791 & & \\
\hline \multicolumn{4}{|l|}{ BEHAVIOURAL INTENTIONS } \\
\hline I will return to stay at a five-star hotel & 0.817 & 0.687 & 0.868 \\
\hline I would recommend five-star hotels to others & 0.851 & & \\
\hline If asked, I would say good things about five-star hotels & 0.819 & & \\
\hline
\end{tabular}

Table 2: Evaluation $\mathrm{R}^{2}$

\begin{tabular}{|l|c|c|}
\hline & R Square & R Square Adjusted \\
\hline Behavioural Intention & 0,523 & 0,513 \\
\hline Satisfaction & 0,320 & 0,311 \\
\hline Service Value & 0,197 & 0,191 \\
\hline
\end{tabular}

Table 3: Collinearity Evaluation

\begin{tabular}{|l|c|}
\hline \multicolumn{2}{|c|}{ As a predictor of Behavior Intentions } \\
\hline Construct & V I F \\
\hline Quality of Service & 1.470 \\
\hline Service Value & 1.509 \\
\hline Satisfaction & 1.324 \\
\hline
\end{tabular}


Table 4: Hypothesis Test Results

\begin{tabular}{|l|c|c|c|}
\hline Hypotheses & Coefficient & $\mathbf{t}_{\text {count }}$ & Results \\
\hline $\begin{array}{l}\text { H1: Consumer satisfaction is positively related to behavioral } \\
\text { intention }\end{array}$ & 0.688 & 9.212 & Support \\
\hline H2: Service value has a positive impact on behavioral intentions & 0.068 & 0.820 & Does not support \\
\hline $\begin{array}{l}\text { H3: There is a positive and direct relationship between the value } \\
\text { of service and satisfaction }\end{array}$ & 0.424 & 4.876 & Support \\
\hline H4: Service quality is positively related to behavioral intention & 0.037 & 0.472 & Does not support \\
\hline $\begin{array}{l}\text { H5: The quality of service is positively related to the satisfaction } \\
\text { of the consumer }\end{array}$ & 0.231 & 2.635 & Support \\
\hline H6: Service quality is positively related to service value & 0.444 & 6.171 & Support \\
\hline
\end{tabular}

\section{Result and Discussion}

\subsection{Evaluation of Measurement Model (Outer Model)}

Validity and reliability tests were carried out on the results of the questionnaire to figure out the measurement model for variables. Validity test shows how well the data collected covers the real area of investigation (Ghauri \& Gronhaug, 2005). The concept of validity is the degree to which a test can measure what it intends to measure (Sawilowsky, 2007; Sireci, 2007). While the reliability test concerns the extent that the measurement of a phenomenon provides stable and consistent results (Carmines \& Zeller, 1979).

Average Variance Extracted (AVE) is the number of indicator variances calculated by the items underlying the construct and must be $>0.5$, so that latent variables explain more than half of the indicator variants (Chin, 1988) and composite reliability must be above 0.7 (Ghozali, 2011) as a standard of the reliability test. The threshold value that generally accepted is 0.7 or more, even though values below 0.7 have been considered acceptable (Hair et al., 2014). Validity testing using discriminant validity refers to the extent to which the construct is actually different from each other empirically. It also measures the level of difference between overlapping constructs (Hair et al., 2014). This study assesses discriminant validity by adjusting the FornellLacker criteria. This method compares the square root of AVE with the latent construct correlation. The construct must describe the variant of the indicator itself better than the other latent construct variant (Fornell \& Larcker, 1981). Therefore, the square root of each AVE construct must have a value greater than the correlation with other latent constructs (Hair et al., 2014).

According to Solimun et al. (2017), a correlation achieves convergent validity if it has a loading value $>0.5$. Based on Table 1, the output shows that the loading factor gives a recommended value of $>0.5$. So, the manifest variable contained in this study is decent. AVE of each construct shows value $>0.5$ and composite reliability value $>0.7$.

\subsection{Evaluation of Structural Model (Inner Model)}

The value of R-Square constructs consumer behavioral intention is worth $52.3 \%$ and the remaining $47.7 \%$ is affected by other factors that are not in this study (see Table 2). Table 3 shows that all indicator items on service quality, service value and satisfaction have values below 5 . Therefore, it says that all indicator items in the latent variable of this study did not have multi collinearity (Hair et al., 2014).

Bootstrap method was used to test the hypothesis in this study on the sample data as much as 5,000 times. To test the hypotheses, a comparison between t-table and $\mathrm{t}$-statistics is important. A value of $\mathrm{t}$-statistics greater than t-table shows that the hypothesis supports the variable and vice versa. The significance level of $95 \%(\alpha=0.05)$ in the one-tailed hypothesis must be $\geq 1.64$ (Hartono, 2011). Based on the processed data shown in Table 4, two hypotheses in this study were rejected or not supported - H2 (service value has a positive effect on behavioral intention) and H4 (service quality is positively related to behavioral intention). Meanwhile, the other hypotheses were accepted or considered supported because the recorded t value was $>$ 1.64 (see Table 4).

Furthermore, the model of the hypothesis test results using PLS is shown in Figure 2. According to the results of the processed data, the physical evidence indicator (tangibility) is eliminated because the outer loading value is below 0.7 and does not support the AVE value of the service quality variable. The four indicators that are not eliminated have a total effect of 0.037 on behavioral intention (Y), of 0.424 on satisfaction and 0.444 on service value variables. Service value (X2), which includes three indicators, has a total influence of 0.068 on the behavioral intention variable. Satisfaction (X3) as an intervention or mediating variable includes three indicators and has a total effect of 0.688 on 
behavioral intentions. An explanation of the evaluation of expenditure models can be seen in Table 2 .

The effect the service quality variable (X1) on the behavioral intention variable (Y) is a direct effect of 0.037 , while the indirect effect through the satisfaction variable (X3) was obtained from $0.231 \times 0.668=0.155$. Then, the total effect of $\mathrm{X} 1$ on $\mathrm{Y}$ is $0.037 \times 0.155=0.192$. Next, the direct effect of service value (X2) on behavioral intention (Y) of 0.068 and the indirect effect through intervention variable (X3) was obtained from $0.424 \times 0.688=0.292$. So, the total effect is $0.068+0.292=0.360$. The result of the indirect effect of $\mathrm{X} 1$ on $\mathrm{Y}$ through $\mathrm{X} 3$ is obtained from $(0.231) \times(0.688)=0.159$. Thus, the total effect is $0.037+$ $0.159=0.196$. For the results of the indirect effect of X2 on Y through X3 of 0.284 obtained from multiplication (0.424) and $(0.668)$ and have a total effect of 0.352 .

\subsection{Discussion}

As shown in Figure 2, satisfaction in this study is modeled as an intervention process or mediating effect. In addition to satisfaction, service quality and service value have a direct effect on consumer behavioral intentions. Service quality and value of five-star hotel services also have an indirect effect because they are mediated through satisfaction. The direct effect of service quality on behavioral intentions is mediated by service value and satisfaction. The indirect effect of service value on behavioral intentions is mediated by satisfaction.

The results of the first hypothesis (H1) support that consumer satisfaction is positively related to behavioral intention. The direct relationship between satisfaction and consumer behavioral intentions is strengthened by much of the literature. Petrick et al. (2001) show that consumers' intention to repurchase is influenced by three factors: past behavior, satisfaction, and perceived value. More specifically, the first hypothesis in this study is supported by another study from Jones and Suh (2000), which states the consumer's behavior intention is determined by overall satisfaction. When consumers are satisfied, the result is a positive evaluation (Soderlund, 2003). Therefore, the positive association between satisfaction of consumers and intention to repurchase is assumed.

The results of the second hypothesis (H2) do not support that the service value has significant impact on hotel guests' behavioral intentions. These results show that the direct effect of service values on behavioral intentions is not significant, so there is no mediating effect on the hypothesis. The majority of respondents who participated indicated that the values regarding five-star hotels such as impressions and rates issued did not greatly affect their behavioral intentions when deciding to stay.

The results of the third hypothesis (H3) support that there is a positive and direct relationship between service value and customer satisfaction. Service value is explained as a global assessment of the product or service that consumers receive from the product. This depends on consumers' thoughts about obtaining and providing services (Lee et al., 2005). In this study, service value mediates the role of variables between service quality and satisfaction with consumer behavior intentions. This shows that the service value obtained in consumer behavior have to be mediated by satisfaction so that it is significant.

The results of the fourth hypothesis (H4) do not support that service quality is positively related to behavioral intention. The majority of the respondents answered the lack of value as one indicator on the service quality variable that was omitted after going through the data processing, namely, physical evidence (tangibility). This means that respondents do not feel that hotels have attractive facilities, well-dressed employees, etc., even though these things are important to them. Therefore, the direct relationship between service quality and behavioral intention of consumers to stay at fivestar hotels is not significant, this indicates that the correlation between the two variables must be mediated by satisfaction, according to the following $\mathrm{H} 5$ results.

The results of the fifth hypothesis (H5) support that service quality is positively related to customer satisfaction. This was supported by a study by Awwad (2012), where consumer satisfaction was mentioned as an important concern for companies and organizations in their efforts to improve the quality of products and services, as well as maintaining consumer loyalty in a very competitive market that encourages consumer behavioral intentions to buy. Hotel guests expect better service from hotels in all dimensions of service quality to increase their satisfaction. They have the lowest perception score on empathy and physical evidence (Al Khattab \& Aldehayyat, 2011).

The results of the last hypothesis (H6) support that service quality is positively related to service value. According to earlier research by Zeithaml (1988), perceived value is a direct antecedent of purchasing decisions and direct consequences of perceived service quality. Cronin et al. (2000) conducted a study in which quality of service, customer satisfaction, and perceptions of the value of the services proposed directly influence the intentions of behavior of consumers. The results of their study posit that service quality and perceived value influence behavior loyalty indirectly through customer satisfaction.

\section{Conclusion and Limitations}

\subsection{Conclusion}

The results of this study show that the direct relationship between service quality and value of five-star hotel services on consumer behavioral intentions do not have a significant 
positive effect. Although they do not have a direct effect on behavioral intention, both of these variables have an indirect effect. Mediation analysis provides support by showing that consumer satisfaction partially mediates the relationship between service quality and service value with the consumers intentions to stay overnight. That is, quality and perceived service value are indirectly influenced by satisfaction. Questionnaires that have distributed show a majority of respondents said that their satisfaction or dissatisfaction greatly influenced behavioral intentions in deciding to stay in a five-star hotel. Satisfaction is a variable that reinforces the variable service quality and service value to get consumer behavior intentions.

\subsection{Limitations}

Proper hypotheses are key to generalizing the mediation model to the hotel industry. But in this study, sampling only consisted of five-star hotel guests, so the hypotheses are limited. Future research could be conducted with respondents who have experience with different types and hotel services to get broader and more complete results. Moreover, the content analysis itself also has several limitations. Therefore, a combination of content analysis and other types of analysis to get more accurate results in the future is recommended.

\section{References}

Al Khattab, S., \& Aldehayyat, J. (2011). Perceptions of service quality in Jordanian Hotels. International Journal of Business and Management, 6(7), 226-233. https://doi:10.5539/ijbm. v6n7p226

Anderson, E. W., Fornell, C., \& Lehmann, D. R. (1994). Customer satisfaction, market share, and profitability: findings from Sweden. Journal of Marketing, 58(3), 53-66. https://doi: $10.2307 / 1252310$

Awwad, M. (2012). An application of the American Customer Satisfaction Index (ACSI) in the Jordanian mobile phone sector. The TQM Journal, 24(6). https:// doi:10.1108/17542731211270098

Becker, E. J. (2009). The proximity hotel: a case study on guest satisfaction of sustainable luxury environment. Master Thesis. Greensboro, NC: The University of North Carolina at Greensboro.

Beerli, A., \& Martin, J. D. (2004). Factors influencing destination image. Annals of Tourism Research, 31(3), 657-681. https://doi. org/10.1016/j.annals.2004.01.010

Bloemer, J. M., \& Kasper, H. P. (1995) The complexity relationship between consumer satisfaction and brand loyalty. Journal of Economic Psychology, 16(1), 311-329. http://dx.doi. org/10.1016/0167-4870(95)00007-B
Buttle, F. (2004). Customer relationship management concept and tools. Oxford, United Kingdom: Elsevier ButterworthHeinemann.

Chin, W. (1998). Issues and opinion on Structural Equation Modeling. Management Information System Quarterly, 22(1). https://www.jstor.org/stable/249674

Choi, K. S., Cho, W. H., Lee, H., \& Kim, C. (2004). The relationships among quality, value, satisfaction and behavioral intention in health care provider choice: A South Korean study. Journal of Business Research, 57(80), 913-21. https://doi.org/10.1016/ S0148-2963(02)00293-X

Chu, Y. (2014). A Review of Studies on Luxury Hotels Over the Past Two Decades. Master of Science Thesis. Ames, IA: Iowa State University.

Cronin Jr., J. J., Brady, M. K., \& Hult, G. T. M. (2000). Assessing the effects of quality, value, and customer satisfaction on consumer behavioral intentions in service environments. Journal of Retailing, 76(1), 193-218. https:/doi.org/10.1016/ S0022-4359(00)00028-2

Danziger, P. N. (2005). Let Them Eat Cake. Marketing Luxury to The Masses as well as The Classes. Chicago, IL: Dearborn Trade Publishing.

Digital Luxury Group. (2013). The World Luxury Index. Retrieved July 26, 2020 from http://www.ehl.edu

Ferdinand, A. (2006). Management Research Methods: Research Guidelines for Thesis, Thesis and Management Science Accompanied. Semarang, Indonesia: Diponegoro University.

Fornell, C., Johnson, M. D., Anderson, E. W., Cha, J., \& Bryant, B. (1996). The American customer satisfaction index: description, findings, and implications. Journal of Marketing, 60(4), 7-18. https://doi:10.2307/1251898

Fornell, C., \& Larcker, D. F. (1981). Evaluating Structural Equation Models with unobservable variables and measurement error. Journal of Marketing Research, 18(1), 39-50. https:// doi: $10.2307 / 3151312$

Ghauri, P. N., \& Gronahaug, K. (2005). Research Methods in Business Studies: A Practical Guide ( ${ }^{\text {rd }}$ ed.). Englewood Cliffs, NJ: Financial Times Prentice Hall.

Ghozali, I. (2011). Multivariate Analysis Application with SPSS Program. Semarang, Indonesia: Diponegoro University Publishing.

Gooding, S. K. S. (1995). Quality, sacrifice, and value in hospital choice. Journal of Health Care Marketing, 15(4), 24-31. https:// doi.org/10.1300/J043v13n02_03

Hair, J., Sarstedt, M., Hopkins, L., \& Kuppelwieser, V. (2014). Partial Least Squares Structural Equation Modelling (PLS-SEM): An Emerging Tool for Business Research. European Business Review, 26(2), 106-128. https:/doi:10.1108/ EBR-10-2013-0128

Hartono, J. (2011). Business Research Methodology: Misunderstandings and Experiences. Yogyakarta, Indonesia: BPFE. 
Hersh, A. M. (2010). Evaluate the Impact of Tourism Services Quality on Customer's Satisfaction. Interdisciplinary Journal of Contemporary Research in Business, 2(6), 1-29. https:// doi:10.1504/IJLTM.2011.038885

Huang, Y. K., \& Feng, C. M. (2009). Why Customers Stay: An Analysis of Service Quality and Switching Cost on Choice Behavior by Catastrophe Model. International Journal of Services Operations and Informatics, 4(2), 107-122. https:// doi:10.1109/SOLI.2006.329008

Jones, M. A., \& Suh, J. (2000). Transaction-Specific Satisfaction and Overall Satisfaction: An Empirical Analysis. Journal of Services Marketing, 14(1), 147-159. https://doi.org/10.1108/08876040010371555

Jones, T. O., \& Sasser, W. E. (1995). Why satisfied customers defect. Harvard Business Review, 73(6), 88-99. https://doi:10.1061/ (ASCE)0742-597X(1996)12:6(11.2)

Kotler, P. (2000). Marketing Management (10 ${ }^{\text {th }}$ ed.). Upper Saddle River, NJ: Prentice-Hall.

Lam, T., \& Zhang, H.Q. (1999). Service quality of travel agents: the case of travel agents in Hong Kong. Tourism Management, 20(3), 341-349. https://doi.org/10.1016/S0261-5177(98)001186

Lee, H. J., \& Seong, M. H. (2020). A Study on the Effects of Business Service Quality on Satisfaction, Commitment, Performance, and Loyalty at a Private University. Journal of Asian Finance, Economics and Business, 7(9), 439-453. doi:10.13106/jafeb.2020.vol7.no9.439

Lee, Y. K., Park, K. H., Park, D. H., Lee, K., \& Kwon, Y. J. (2005). The Relative Impact of Service Quality on Service Value, Customer Satisfaction, and Customer Loyalty in Korean Family Restaurant Context. International Journal of Hospitality \& Tourism Administration, 6(1), 27-51. https://doi:10.1300/ J149v06n01 03

Maroco A. L., \& Maroco, J. (2013). Service quality, Customer Satisfaction and Loyalty in 4- and 5-Star Hotels. European Journal of Tourism, Hospitality and Recreation, 4(3), 119-145.

McDougall, G. H., \& Levesque, T. (2000) Customer satisfaction with services: Putting perceived value into the equation. Journal of Services Marketing, 14(1), 392-410. https://doi. org/10.1108/08876040010340937

Mclean, J. (2019, June 26). What Makes a Hotel 5-Star? Retrieved from https://www.tripsavvy.com

Mohsin, A., \& Lockyer, T. (2010). Customer Perceptions of Service Quality in Luxury Hotels in New Delhi, India: An Exploratory Study. International Journal of Contemporary Hospitality Management, 22(2), 160-173. https://doi. org/10.1108/09596111011018160

Morash, W. A., \& Ozment, J. (1994) Toward management of transportation service quality. Logistics and Transportation Review, 30(1), 115-140.

Mulyono, H., Hadian, A., Purba, N., \& Pramono, R. (2020). Effect of Service Quality Toward Student Satisfaction and Loyalty in Higher Education. Journal of Asian Finance, Economics and Business, 7(10), 929-938. doi:10.13106/jafeb.2020.vol7. no10.929

Oh, H. (1999). Service quality, customer satisfaction, and customer value: A Holistic perspective. International Journal of Hospitality Management, 18(1), 67-82. https://doi.org/10.1016/ S0278-4319(98)00047-4

Oliver, R. L. (1980). A Cognitive Model of the Antecedents and Consequences of Satisfaction Decisions. Journal of Marketing Research, 17(4), 460-469. https://doi:10.2307/3150499

Oliver, R. L., Rust, R., \& Varki, S. (1997). Customer Delight: Foundations, Findings and Managerial Insight. Journal of Retailing, 73(1), 311-336. https://doi.org/10.1016/S00224359(97)90021-X

Parasuraman, A. P., Zeithaml, V. A., \& Berry, L. L. (1988). SERVQUAL: A multiple- Item Scale for measuring consumer perceptions of service quality. Journal of Retailing, 64(1), 12-40.

Park, J. W., Robertson, R., \& Wu, C. L. (2004). The effect of airline service quality on passengers' behavioral intentions: A Korean case study. Journal of Air Transport Management, 10(6), 435439. https://doi.org/10.1016/j.jairtraman.2004.06.001

Petrick, J., Morais, D., \& Norman, W. (2001). An Examination of the Determinants of Entertainment Vacationers' Intentions to Revisit. Journal of Travel Research, 40(1), 41-48. https:// doi:10.1177/004728750104000106

Sawilowsky, S. S. (2007). KR-20 and KR-21. In: N.J. Salkind (Ed.). Encyclopedia of Measurement and Statistics ( $1^{\text {st }}$ ed., pp. 516-519). Thousand Oaks, CA: Sage Publications.

Sireci, S. (2007). On Validity Theory and Test Validation. Educational Researcher, 36(8), 477-481. https:// doi:10.3102/0013189X07311609

Soderlund, M. (2003). The Retrospective And The Prospective Mind And The Temporal Framing of Satisfaction. European Journal of Marketing, 37(10), 1375-1390. https://doi. org/10.1108/03090560310487158

Solimun, Fernandes, A. A. R., \& Nurjannah. (2017). Multivariate Statistical Methods for Structural Equation Modelling (SEM) WarpPLS Approach. Malang, Indonesia: Brawijaya University Press.

$\mathrm{Su}$, A. Y. (2004). Customer Satisfaction Measurement Practice in Taiwan Hotels. International Journal of Hospitality Management, 23(1), 397-408. https://doi.org/10.1016/j. ijhm.2004.02.002

Tran, V. D. (2020). Assessing the Effects of Service Quality, Experience Value, Relationship Quality on Behavioral Intentions. Journal of Asian Finance, Economics and Business, 7(3), 167-175. https://doi:10.13106/jafeb.2020.vol7.no3.167

Tran, V. D \& Le, N. M. T. (2020). Impact of Service Quality and Perceived Value on Customer Satisfaction and Behavioral Intentions: Evidence from Convenience Stores in Vietnam. 
Journal of Asian Finance, Economics and Business, 7(9), $517-$ 526. doi:10.13106/jafeb.2020.vol7.no9.517

Wakefield, K. L., \& Barnes, J. H. (1996). Retailing Hedonic Consumption: A Model of Sales Promotion of a Leisure Service. Journal of Retailing, 72(4), 409-427. https://doi.org/10.1016/ S0022-4359(96)90021-4

Warshaw, P. R., \& Davis, F. D. (1985). Disentangling Behavioral Intention and Behavioral Expectation. Journal of
Experimental Social Psychology, 21(3), 213-228. https://doi. org/10.1016/0022-1031(85)90017-4

Zeithaml, V. A. (1988). Consumer Perceptions of Price, Quality, and Value: A Means-End Model and Synthesis of Evidence. Journal of Marketing, 52(3), 2-22. https://doi:10.2307/1251446

Zeithaml, V. A., Berry, L. L., \& Parasuraman, A. P. (1996). The Behavioral Consequences of Service Quality. Journal of Marketing, 60(1), 31-46. https://doi:10.2307/1251929 